\title{
The Perceptions about Islamic Banks: Study at Islamic Boarding School Al-Hikamussalafiyah Purwakarta
}

\author{
Jalaludin $^{1}$, Abdul Bari Saadi ${ }^{2}$ \\ \{jalaludin@sties-purwakarta.ac.id ${ }^{1}$ \} \\ Sharia Economics Study Program, STIE Syariah Indonesia Purwakarta, 41118, Indonesia ${ }^{1,2}$
}

\begin{abstract}
This article focuses on the discussion of the perceptions of santri, ustadz and caregivers of the Cipulus Wanayasa Purwakarta Islamic Boarding School of AlHikamussalafiyah Islamic Boarding School, and the attitude of students, religious teachers and caretakers of the Cipulus Wanayasa Purwakarta Islamic Boarding School of AlHikamussalafiyah Islamic Boarding School. The method used in this research is a descriptive study with a qualitative approach. The attitudes and decisions of the students not to choose an Islamic bank are influenced by the distance of the Islamic bank ${ }^{\wedge} \mathrm{s}$ location and the uncertain legal basis. Meanwhile the students decision to choose a conventional bank is determined by the ease of accessing conventional banks and their services. Even though the students perceptions of bank interest are positive, it is not enough to convince students to choose Islamic banks. The perceptions and attitudes of the Ustadz at the Cipulus Wanayasa Al-Hikamus-salafiyah Islamic Boarding School were positive, indicated by their agreement with the basic principles of Islamic banking. But in reality, the communication or promotion carried out by Islamic financial institutions is not optimal. Even though promotion is very effective for socialization, forming the image of sharia banking and changing people is behavior at the Cipulus Wanayasa Al-Hikamussalafiyah Islamic Boarding School towards the sharia financial system.
\end{abstract}

Keywords: Perceptions, Islamic banks, Islamic boarding schools.

\section{Introduction}

Islamic banking is an Islamic banking system that emphasizes ethics, morals that mutually agree and respect each other [1]. The system builds a value that becomes the basis for regulation and development, as well as the values that must be applied in banking operations of individuals who transact following the Prophet's immortality through their characteristics, namely siddiq, amanah, tabliqh, and fathonah. It would be very noble if this system was actually implemented in every activity or economic transaction. In addition, the Islamic banking system also implements 4 (four) values which are often called the principal values of Islamic economics, namely: ta'awun (cooperation), ti'ayah (professional management), masuliyah (responsibility), and fastabiqhul khairat (continuously to make improvements) [2].

The basic principle in the function of a sharia bank adheres to 3 (three) main functions (accepting deposits of funds, lending money, and money transfer services), that is, it is permissible to do it unless the banking function performs things that are prohibited by sharia. In today's conventional banking practice, this function is carried out based on the principle of interest. Conventional banks are not necessarily synonymous with usury, but most conventional banking practices can be classified as ribawi transactions. According to Totok [3], a sharia bank 
is a bank that both in raising funds and in the framework of channeling funds provides and charges compensation based on sharia principles, namely buying and selling and profit sharing. The main principle of the bank in its operation is based on sharia principles, in view of Islamic law which is derived from the Al-Qur'an and Hadith.

Institutionally, syari'ah banks act as financial institutions that use a relatively new system. Of course, there is still a lot of information that needs to be disseminated in practice. Obviously, every step of the way by jointly improving the system, efforts to improve the existing system are always made. Seeing this, Bank Indonesia has compiled, discussed, and taken the initiative to develop Islamic banks in a comprehensive manner, namely the development of sharia principles, regulations regarding bank prudence, efficiency in carrying out operations and stability of the Islamic banking system [4]. The development of Islamic banks is increasingly growing and developing in several regions in Indonesia, this shows the progress of Islamic banks in the managerial side. In Purwakarta Regency, for example, several sharia bank branch offices have been established. With the existence of Islamic banks, Muslims are protected from usury in their muamalah activities and in accordance with the orders of their religion.

In addition, Purwakarta is known as the city of santri, because Purwakarta Regency is rich in Islamic boarding schools, almost in every district and village there is a pesantren. Where, according to Syahid Ali, that pesantren is a non-formal, traditional Islamic educational institution that studies, understands, deepens, lives, and practices Islamic teachings by emphasizing the importance of religious morals as guidelines and guides for daily behavior. In addition, Islamic boarding schools are taught how to have a congregation in accordance with Islamic law. Books related to this were studied by many students, one of which was the book of Fathul Qarib / Taqrib fiqih Imam Syafi'i, which was compiled by Shaykh Syamsuddin Abu 'Abdillah, Muhammad bin Qasim Rahimahumullah. So that some Islamic economic principles are taught in several Salafiyah Islamic Boarding Schools in Purwakarta. Pondok Pesantren alHikamussalafiyyah Wanayasa Purwakarta, better known as Pondok Pesantren Cipulus. This Islamic boarding school was first established in 1840, founded by KH Muhammad / Ahmad Bin Kyai Nurkoyyim who is familiarly known as Ajengan Emed. He is the favorite student of Syeikh Maulana Yusuf Purwakarta, namely the great scholar and hero in West Java in the early 19th century, Ajengan Emed is a diligent student, has a high leadership spirit, so that he can easily absorb the knowledge given by his teacher, either Religion and science of war strategy and other sciences needed at that time. When the Dutch exerted intense pressure on the Indonesian people, he was determined to establish a pesantren. The goal is to gather students to spread the Islamic religion and help achieve independence. Armed with the knowledge he had in 1840, a simple Islamic boarding school was founded in the area of the former capital of Karawang, in the current Wanayasa District, Purwakarta Regency. The pesantren was held directly by Ajengan Emed until the end of his life, after he died, this pesantren was continued by KH Nasyir (1870 - 1900), KH M arief (1900 - 1920), Kyai Sueb (1920 - 1937), KH Masduki (1937-1942), and KH Z Abidin (1942 - 1957).

With this development, the Cipulus Islamic boarding school has an outline of the pesantren policy which is then refined into the basic pattern and development of the Al-Hikamussalafiyyah Islamic Boarding School which is based on (1) Tafaqquh Fi al-din, (2) Da'wah, (3) Ta'awun, (4) Deliberation, (5) Ukhuwah Islamiyah, and aiming at long-term fostering and developing laughter for Allah SWT to develop useful science and dedication to religion, society and the State, with the aim of having good educational standards, by developing education with a system integrated and new educational methods, cooperating with various parties in order to improve the quality of education effectiveness. 
This article focuses on the discussion of the perceptions of santri, ustadz and caregivers of the Cipulus Wanayasa Purwakarta Islamic Boarding School of Al-Hikamussalafiyah Islamic Boarding School; and the attitude of students, religious teachers and caregivers of the Cipulus Wanayasa Purwakarta Islamic Boarding School of Al-Hikamussalafiyah Islamic Boarding School.

\section{Method}

The method used in this research is a descriptive study with a qualitative approach. Morce suggests that the main design in qualitative planning consists of several stages (Stages). First, reflection as a stage of thought that tries to look at the problems to be studied. accompanied by a deep understanding so that topics can be determined or selected to be the object of research. Second, planning as the the stage of selecting a research place that is in accordance with the problem to be studied, then what strategies will be applied in obtaining the required data. Third, data collection to ensure confidence. Determining the data eligibility criteria is the first step in this stage. Careful documentation about the development of research should provide convincing evidence so that other parties can reconstruct the research process until a conclusion is reached. Fourth, withdrawal. Qualitative research is carried out in a natural setting, this will result in a situation where the researcher will be seen and see himself as part of the setting because he is very familiar with the object of the research / informant. This situation resulted in the researcher being less sensitive to the data that should have been extracted so that it could hinder the data collection process. Fifth, writing research results [5].

\section{Results and Discussion}

\subsection{Perceptions of santri, ustadz and caregivers of the cipulus wanayasa Purwakarta}

Islamic Boarding School of Islamic Boarding School The findings from the results of interviews with students of the Al Hikamussalafiyyah Islamic Boarding School Cipulus Wanayasa Purwakarta is that there are differences in perceptions of Islamic banks among the students and their leaders. Meanwhile, the santri are not yet interested in using Islamic banking services, even though they have already gained a lot of knowledge about muamalah in recitation at the Islamic boarding school, so they no longer have a conventional mindset. In fact, these students can be said to be successful in managing the pesantren cooperative in the Islamic boarding school. They prefer to use the pesantren economy.

Massively, at Pondok Pesantren Al-hikamussalafiyah Cipulus Wanayasa Purwakarta, for now, students still use conventional bank services, especially since their image of the operational practices of Islamic banks is no different from conventional banks, so they have no consideration of moving to an Islamic bank. Whereas in theory the operational of Islamic banks with conventional banks is very different, one of which is public funds in the form of deposits and investments that will only get results if cultivated first, whereas in conventional banks public funds are in the form of deposits that must be paid interest at maturity.

Most of the students were of the opinion that when several banks under the name sharia had expanded to various regions, the halal-haram provisions were not yet reliable and were not sufficiently convincing among the pesantren. The pesantren is of the opinion that the issue of 
business promotion should not be too religious. In fact, the approach of Islamic banks which emphasizes more on emotional aspects must be reduced. Sharia banks should be expected to prioritize professionalism and prioritize excellent service to customers. If this is done optimally, it is certain that the students will have more confidence in Islamic banks. Obviously, Islamic banks must be able to convince the public that Islamic banks are better. This can be a challenge in itself for Islamic banks to erase this image that has been built for a long time and to realize one of the objectives of Islamic banks, namely directing the economy of the people to embrace Islam, especially muamalah which is related to banking, so that it is farthest from usury practices or other types of -Other types of businesses that contain elements of gharar (hoax), where these types of businesses are not only prohibited in Islam, but also have a negative impact on the economic life of the people, especially the economy of Muslims in Indonesia.

Then, the next analysis is from the students who claim to already know about Islamic banks, in their eyes an Islamic bank is a bank that is said to use a profit sharing system, of course a bank based on Islamic teachings, namely a bank that is in accordance with the principles of sharia. It seems that none of the students have economic reasons, for example saying that Islamic banks are more profitable economically. The bank is only an intermediary whose function is only as a means of transferring money for certain purposes. For example, for the purpose of paying for hajj because it is impossible not to go through a bank appointed by the government or related agencies.

In addition, the opinions of some students and other ustadz show that in theory the operational system of a sharia bank has met sharia principles, but unfortunately they do not fully understand its practical performance. This proves that the operational concept of Islamic banks in theory has met Islamic principles, for example in the product of channeling funds, banks as investors and customers as capital managers, the results of the management of these funds will be divided according to the initial agreement. However, in practice it does not comply with sharia principles because at the time the fund processor experiences losses, and the worst thing is that sometimes the bank does not want to share the loss together. For this reason, the students think that sharia principles have not been used in every transaction at Islamic banks in Indonesia.

The perception of banks, according to Ustadz, is that there is no difference between the practice of Islamic banking and conventional banks, because when customers apply for venture capital financing they experience losses, in their view that the losses will be borne together, it is not. That is what in their view contains the element of gharar. A technique to convince customers, but in the future if a loss occurs, it is not shared. The bank sometimes convoluted in handling the loss cases. It is clear, meaning that previously there was no contract between the customer and the bank which made the customer not aware of the function of the contract they had automatically agreed to. In general, Islamic banks should be more careful and thorough in every transaction. The application of sharia principles regulations must be used in every transaction according to each product of the Islamic bank. not only used in certain transactions.

The perception of banks according to Ustadzdah is that there is no difference between the practice of Islamic banking and conventional banks, because when customers apply for business capital financing they experience losses, in their view that the losses will be borne together, it is not. That is what in their view contains the element of gharar. A technique to convince customers, but in the future if a loss occurs, it is not shared. The bank sometimes convoluted in handling the loss cases. It is clear, meaning that previously there was no contract between the customer and the bank which made the customer not aware of the function of the contract they had automatically agreed to. In general, Islamic banks should be more careful and thorough in every transaction. The application of sharia principles regulations must be used in every transaction according to each product of the Islamic bank. not only used in certain transactions. 
This perspective begins to taper, that the knowledge and information received by students about the products and contracts of Islamic banks is minimal. This means that the socialization of Islamic banks is highly recommended to inform the systems, products and mechanisms of Islamic banks to each pesantren. Of course what is meant, the socialization does not just introduce the existence of Islamic banks, but also introduces the mechanisms, products of Islamic banks and other instruments regarding Islamic bank finance to the boarding school community.

From the results of interviews, respondents in the field showed a tendency not to know about the questions about the performance and products offered by Islamic banks. The reason is that their knowledge is still superficial and their interactions with Islamic banks are still limited by distance, time and number of banks. The perception of students towards Islamic banks is still limited to legal aspects, namely products that are not usury and halal.

The views of the santri, which according to the author represent the perceptions of the students at the Al-Hikamussalafiyah Wanayasa Purwakarta Islamic Boarding School, that the law of haram on interest as stated in the MUI fatwa has not been able to change the santri's belief about Islamic banking. Even though the santri support the fatwa on the prohibition of bank interest, the santri have not yet planned to switch to Islamic banks because the students are still unsure about the halalness of the profit sharing.

From the results of interviews, respondents in the field showed a tendency not to know about the questions about the performance and products offered by Islamic banks. The reason is that their knowledge is still superficial and their interactions with Islamic banks are still limited by distance, time and number of banks. The perception of students towards Islamic banks is still limited to legal aspects, namely products that are not usury and halal.

The views of the santri, which according to the author represent the perceptions of the students at the Al-Hikamussalafiyah Wanayasa Purwakarta Islamic Boarding School, that the law of haram on interest as stated in the MUI fatwa has not been able to change the santri's belief about Islamic banking. Even though the santri support the fatwa on the prohibition of bank interest, the santri have not yet planned to switch to Islamic banks because the students are still unsure about the halalness of the profit sharing.

\subsection{Attitudes of santri, ustadz and uaregivers of the cipulus wanayasa Purwakarta islamic boarding school of islamic boarding school}

The theory regarding the operational concept of Islamic banks has fulfilled the actual principles of sharia, namely that banks collect funds from the public and channel funds to the community for halal businesses. However, respondents do not really understand the practice in the field, so the funds channeled to the community for halal businesses should also come from halal fundraising as well. However, in the practice of collecting funds, only a certain amount of savings is asked of the source of funds deposited by customers. Because of this, the boarding school community still doubts its syari'ah practice of the concept of raising funds.

Seeing the concept of Islamic banking that has developed, the pesantren (both santri and ustadz / kiyai), they are of the opinion that they have not fully complied with sharia principles. There are still rules of sharia principles that have not been used in the operational practice of Islamic banks, namely the qobul consent process between the bank and the customer making the transaction. One example, such as when a customer saves at a bank, there is no agreement between the bank and the customer, whether the customer wants to save with a wadi'ah or mudharabah contract or which contract. The customer is only presented with a paper containing the regulations from the bank to be approved and signed, then a stamp is attached, as if forced 
to agree. Meanwhile, what is called a contract is when both parties say the consent qobul to obtain a mutual agreement. So there is a system of installments and profit taking in Islamic banks in general, Islamic banks have not fulfilled Islamic law. Meanwhile, what is taught in the pesantren, Islamic law is exemplified as the Prophet's behavior when congregating. At that time when the Prophet kept the money entrusted, of course the Prophet returned it completely without asking or taking a penny from a friend. However, if the bank does not have an installment or profit-taking system, there will be no funds to pay employee salaries. Not yet discounted ATM fees and transfers between different banks. This is what makes the students prefer conventional banks.

Based on the results of an interview with one of the employees from the Ministry of Religion of Purwakarta Regency, stated that Islamic banks in Indonesia are very helpful for the growth and equity of the National economy. The existence of doubts from some Muslim communities about Islamic banks and consider Islamic banks the same as conventional banks in general, this happens because of a lack of understanding of the essence of Islamic economics. In this case, of course, it takes hard work from Islamic banking actors to disseminate and educate the public about Islamic banking. From another opinion, it is also stated that the concept of Islamic banking is sufficient to comply with sharia principles or qirod rules, namely an alliance of two people, one as an investor, one as a business actor with an agreement of loss or profit being shared. However, they said that they did not have a clear source. It is only argumentative.

\section{Conclusion and Suggestion}

\subsection{Conclusion}

Based on the analysis above, the writing can draw the conclusion that, the perception of AlHikamussalafiyyah Cipulus wanayasa Purwakarta students both who are customers of Islamic banks and non-customers of Islamic banks, stated positive about the existence of Islamic banks. However, they are still not interested in joining Islamic banks because they see several considerations, such as the law of halal-haram, ATMs that are still rarely found and the santri population who are still comfortable with conventional banks. Meanwhile, the difference between customer and non-customer santri is in their attitude or choice to choose and not to choose an Islamic bank. The attitude and decision of the students not to choose an Islamic bank is influenced by the distance between the location of the Islamic bank and the uncertain legal basis. Meanwhile the students' decision to choose conventional banks was influenced by the ease of accessing conventional banks and their services. Even though the students' perceptions of bank interest are positive, it is not enough to convince students to choose Islamic banks.

The perceptions and attitudes of the Ustadz at the Cipulus Wanayasa Al-Hikamussalafiyah Islamic Boarding School were positive, indicated by his agreement to the basic principles of Islamic banking. But in reality, the communication or promotion carried out by Islamic financial institutions is not optimal. Even though promotion is very effective for socialization, forming an image and changing people's behavior at the Cipulus Wanayasa Al-Hikamussalafiyah Islamic Boarding School towards the Islamic financial system. Meanwhile, Islamic banks in the perspective of the Cipulus Wanayasa Purwakarta Alhikamussalafiyyah pesantren, even though the concept of Islamic banking is good, the current practice of Islamic banking still shows a mismatch with the existing Islamic concept. 


\subsection{Suggestion}

The attractiveness of Islamic banks is of course influenced by the service factor and the ease of accessing the bank. Therefore, it is hoped that Islamic banks can continue to develop banking services, in this case, of course, it requires hard work from Islamic banking actors to disseminate and educate the public about Islamic banking and optimize the professionalism of their human resources, not only prioritizing halal principles. usury.

Researchers have high hopes, that for further research, similar research should be carried out in other Islamic banks by adding other factors that are considered more influencing customers to choose Islamic banks. In order to improve the Islamic banking system and to socialize its products, for the sake of the economic progress of Muslims.

\section{Acknowledgment}

This research was not funded by any institution or institution, the authors would like to thank all those who have helped this research, especially the Santri, administrators and carers of the Cipulus Wanayasa Purwakarta Al-Hikamussalafiyah Islamic Boarding School.

\section{References}

[1] M. Mansur, "BANK SYARIAH : Antara Labelisasi dan Pemberdayaan Ekonomi Masyarakat," Ulumuna J. Stud. Keislam., vol. 4, no. 1, pp. 54-70, Jun. 2018, doi: 10.36420/ju.v4i1.3547.

[2] A. Majid, Keutamaan Bank Islam. Jakarta: Graha Pers, 2009.

[3] T. Budisantoso, Bank dan Lembaga Keuangan Lain, 2nd ed. Jakarta: Salemba Empat, 2006.

[4] H. Sudarsono, Bank Dan Lembaga Keuangan Syari'ah. Yogyakarta: Ekonisia, 2003.

[5] J. M. Morse, Designing funded qualitative research. In N. K. Denzin \& Y. S. Lincoln (Eds.), Handbook of qualitative research. New York: Sage Publications, Inc, 1994. 